\title{
ORIGANUM VULGARE И МОЛОЧНАЯ СЫВОРОТКА КАК КОМПОНЕНТЫ НОВОГО ФУНКЦИОНАЛЬНОГО НАПИТКА
}

\author{
Е.С. Алешина, Е.А. Дроздова
}

Оренбургский государственный университет, 460013, г. Оренбург, пр. Победы, 13

РЕЗЮМЕ. В настоящее время пятая часть взрослого населения России, включая жителей Оренбургской области, страдает не только полидефицитным состоянием в отношении витаминов, микро- и макроэлементов, но и пониженным иммунным статусом вследствие перенесенных инфекционных заболеваний, в том числе и вирусной природы. Были оценены основные показатели молочной сыворотки пастеризованной (титруемая и активная кислотность, общая обсемененность и количество бактерий рода Lactobacillus), антибактериальные характеристики растительного сырья на примере Origanum vulgare. Показано, что добавление в молочную сыворотку эстрактов растительного сырья $O$. vulgare приводит не только к обогащению и без того полезной молочной сыворотки витаминами, микро- и макроэлементами, но и увеличение срока годности продукта.

КЛЮЧЕВЫЕ СЛОВА: микро- и макронутриенты, функциональные напитки, молочная сыворотка, растительные экстракты.

\section{ORIGANUM VULGARE AND MILK SERUM AS COMPONENTS OF NEW FUNCTIONAL DRINKS}

\author{
E.S. Aleshina, E.A. Drozdova \\ Orenburg State University, 460013, Orenburg, Pr. Pobedy 13
}

ABSTRACT. Currently, a fifth of the adult population of Russia, including residents of our region, suffers not only from a polydeficiency condition with respect to vitamins, micro- and macroelements, but also from a reduced immune status due to infectious diseases, including viral nature. We evaluated the main indicators of pasteurized milk serum (titrated and active acidity, total insemination and number of bacteria of the genus Lactobacillus), the antibacterial characteristics of plant raw materials on the example of Origanum vulgare and determined that the addition of $O$. vulgare plant raw material extracts to milk serum leads not only to the enrichment of already useful milk whey with vitamins, micro- and macroelements, but also to an increase in the shelf life of the product.

KEYWORDS: micro- and macronutrients, functional beverages, milk serum, extracts of plants.

\section{ВВЕДЕНИЕ}

Недостаточное поступление микронутриентов с пищей - общая проблема всех стран. К технологиям обогащения рациона относится совместное использование сырья животного и растительного происхождения, в частности комбинированных молочнокислых продуктов, содержащих экстракты растений, богатых витаминами, биофлавоноидами, антиоксидантами, дубильными веществами, макро- и микроэлементами (Bazarnova, 2006; Chun at al., 2007, Шавыркина и др., 2018).

Цель исследований - оценка влияния экстракта $O$. vulgare на качество напитков функционального питания на основе молочной сыворотки.

\section{МАТЕРИАЛЫ И МЕТОДЫ}

Для оценки основных показателей молочной сыворотки пастеризованной и напитка на его основе, а также антибактериальных характеристик растительного сырья Origanum vulgare проводили посев на среды ГРМ и MRS и подсчет KOE, определение каталазной активности микроорганизмов. Экстракты растительного сырья получали пропариваем. Полученные результаты анализировали с использованием непараметрической статистики по Манна-Уитни (программа Statistica 6.0 для Windows). 


\section{РЕЗУЛЬТАТЫ И ОБСУЖДЕНИЕ}

Первоначальная оценка показателей качества исследуемых образцов молочной сыворотки соответствует параметрам, регламентированным нормативными документами. В течение всего срока хранения каждого образца молочной сыворотки происходит увеличение численности бактерий рода Lactobacillus и в следствие этого нарастание ее титруемой кислотности и понижение активной кислотности. Впоследствии данный процесс приостанавливается и отмечается заметное снижение количества бактериальных колоний и рост количества колоний плесневых грибов и дрожжей.

Минимальная подавляющая концентрация $O$. vulgare, вызывающая достоверную гибель микроорганизмов, составила 200 мг/мл. Добавление $O$. vulgare вело к снижению титруемой и активной кислотности молочной сыворотки, уменьшению количества развивающейся микрофлоры и менее выраженному нарастанию количества плесневых грибов и дрожжей по отношению к исходным образцам молочной сыворотки. Таким образом, добавление O. vulgare в молочную сыворотку прогнозируемо увеличивает срок хранения продукта, сохраняя и продлевая свойства получаемого напитка.

\section{ВЫВОДЫ}

Полученные данные позволят получить инновационные продукты на основе молочной сыворотки с добавлением экстрактов растений с пролонгированным сроком хранения и с улучшенными вкусовыми и качественными характеристиками.

\section{Список литературь}

1. Шавыркина Н.А., Обрезкова М.В., Школьникова М.Н. Характеристика ферментативных напитков на основе молочной сыворотки и фруктового сока. Вестник КрасГау. 2018; 2: 112-116.

2. Bazarnova Y.G. Study of the flavonoid composition of herbal extracts spectral methods. Voprosy pitaniia Problems of Nutrition. 2006; $1: 5-41$.

3. Chun O.K., Chung S.J., Song W.O. Estimated Dietary Flavonoid Intake and Major Food Sources of U.S. Adults. American Society for Nutrition J. Nutr. 2007; 137(5): 1244-1252.

\section{References}

1. Shavyrkina N.A., Obrazkov M.V., Shkolnikov M.N. Characterization of fermentative beverages based on milk whey and fruit juice. Westnik Kras Gau. 2018; 2: 112-116.

2. Bazarnova Y.G. Study of the flavonoid composition of herbal extracts spectral methods. Voprosy pitaniia Problems of Nutrition. 2006; $1: 5-41$.

3. Chun O.K., Chung S.J., Song W.O. Estimated Dietary Flavonoid Intake and Major Food Sources of U.S. Adults. American Society for Nutrition J. Nutr. 2007; 137(5): 1244-1252. 